\title{
Identification of Obstacles to Implementing Sustainability in the Civil Construction Industry Using Bow-Tie Tool
}

\author{
Emanuelly L.G. da Trindade ${ }^{1}$, , Luanda R. Lima ${ }^{2}$, Luciana H. Alencar ${ }^{2, *}$ \\ and Marcelo H. Alencar ${ }^{2}$ \\ 1 Instituto Federal de Educação, Ciência e Tecnologia do Sertão Pernambucano, \\ Serra Talhada PE 56915-899, Brazil; emanuelly.trindade@ifsertao-pe.edu.br \\ 2 Department of Management Engineering, Universidade Federal de Pernambuco, Recife PE 50740-550, Brazil; \\ luandar.lima@gmail.com (L.R.L.); marceloalencar@cdsid.org.br (M.H.A.) \\ * Correspondence: luciana.alencar@ufpe.br
}

Received: 6 August 2020; Accepted: 9 September 2020; Published: 14 September 2020

check for updates

\begin{abstract}
The construction industry is responsible for causing a large adverse impact on the environment. To minimize these impacts, sustainable practices are being sought mainly in the area of the wastage of and the waste from raw materials. Many obstacles and difficulties are encountered when trying to implement sustainable practices in civil construction. Thus, a study to identify what the obstacles are to implementing such practices is necessary. Therefore, the objective of this study is to present an assessment of the main obstacles to implementing sustainability in civil construction for which the bow-tie tool is used. Three cases were analyzed: construction material waste, the wastage of plaster and planning a sustainable construction project. Results showed that the lack of planning for sustainable construction projects, the lack of compliance with technical standards and the lack of technical knowledge of the workforce and of standardization are among the main obstacles to implementing sustainability in civil construction. This study offers a structured methodology to identify causes, consequences and obstacles related to events that affect the implementation of sustainable practices. It provides a visualization of the scenario investigated through the diagram generated, facilitating its understanding and analysis.
\end{abstract}

Keywords: civil construction; sustainability; bow-tie

\section{Introduction}

The construction industry is responsible for making a large adverse impact on the environment, both by generating waste materials and by producing greenhouse gases, as a result of using energy and consuming resources. Consequently, all of these induce negative environmental loads on the ecosystem. In recent years, according to Hossain and $\mathrm{Ng}$ [1], the importance of implementing sustainability in civil construction has been noted. Therefore, selecting materials of low impact, managing waste materials and reducing wastages in sustainable construction works are gaining more and more space in the market and in decision making, in order to develop strategies and thereby to transform operations of traditional activities into sustainable activities [2-5].

Currently, due to the rapid growth in the population and urbanization in various parts of the world, the amount of construction waste material is increasing and one of the biggest challenges is managing and reducing this waste to achieve goals that promote sustainability in organizations [6-9]. However, using greener practices in the context of civil construction is still considered by many entrepreneurs as a burden (on normal practices) that leads to increased costs and reduced profits for 
companies in the sector [10]. Therefore, it is still possible for there to be buildings under construction for which decision-makers (DMs) have great difficulty in implementing sustainable development in a strategic and efficient manner.

To tackle this, causes of wastages of materials in this sector need to be identified to determine actions and factors that contribute to the loss of inputs to reduce and mitigate negative impacts on the environment [11,12]. Thus, bow-tie analysis has been demonstrated to be suitable for supporting decision making, as it is used to conduct a scenario analysis of a given event [13]. The first thing to be done is to seek to identify the leading causes of wastages and then the main consequences, making it then possible to suggest protection barriers to decrease potential threats or to improve opportunities linked to the objectives of a construction project.

In previous studies, which present the general relationship between cause and effect, the main reasons that hinder the implementation of green areas in urban systems have been explored. These include increased maintenance costs, increased design and construction costs and lack of organization when creating green areas, in addition to the lack of incentives for DMs [14,15]. Another study identified employees' lack of awareness and the rejection and non-compliance with the standards of the construction project as the main causes of non-conformity in buildings under construction [16].

Yeganeh et al. [17] identified problems and effects in Iranian construction projects. They made contact with experts in the area, and identified that the justifications for projects not performing favorably were the public culture and the non-understanding of the implications of some of the terminology used in construction projects. Seyis et al. [18] identified and classified the types of waste materials and the root causes of waste and wastage, based on what impact these have on increases in the elapse of time and costs during the design and construction phases.

Therefore, studies on obstacles to implementing sustainability in civil construction should be analyzed. They should consider the main causes and consequences of adverse events and the problems associated with protection. This should be done during the planning stage of sustainable construction projects, when managing such projects with respect to construction materials, as it is important to understand the causes and effects to foster implementing environmental, economic and social benefits.

No studies were found in the literature review regarding the identification of protective barriers, to reduce the effects of the consequences of generating waste material, and preventive barriers, to reduce threats that can cause an event such as wastage of materials. Thus, we propose the use of the bow-tie tool to fill this gap in the literature, identifying the main obstacles to implementing green practices in construction and thus addressing the possible consequences for the organization, besides the protective and preventive barriers.

In this context, this paper aims to present a structured methodology to deal with the problem of implementing sustainability in civil construction based on the bow-tie tool. It provides a structured analysis, with gains in visualizing information and in defining preventive and mitigation actions $[13,19]$. Previous studies have used bow-tie in other areas, such as to assess accidents at work on oil platforms [20], in the health sector [21] and in the naval industry [13]. Despite the help that this tool offers, bow-tie is not widely used in the construction industry, thus reinforcing the relevance of this study, which is to contribute towards making more assertive management decisions, since DMs will have a better understanding of the event itself.

Therefore, to address important aspects in construction, this tool was applied in the analysis of three scenarios concerning vertical construction works in Recife, Brazil: first, the wastage of construction materials in general; secondly, the wastage of gypsum from the perspective of the service provider; and, thirdly, the planning of a sustainable construction site.

The paper is structured as follows: Section 2 describes sustainability in civil construction, while Section 3 presents the bow-tie tool. Section 4 offers the Materials and Method section. Section 5 puts forward the results of the framework application in the three cases analyzed. Finally, Section 6 engages in analysis and discussion and presents the future directions of the study. 


\section{Sustainability in Civil Construction}

For the purpose of this study, sustainability will be discussed in the context of organizations. According to Gilbert Silvius et al. [22], organizational sustainability occurs by adopting business strategies and activities that meet the needs of the company and its stakeholders today, with regard to protecting the human and natural resources that will be needed in the future. Martens and Carvalho [23], on the other hand, defined it as a business approach that creates, in the long term, value for stakeholders by taking advantage of opportunities and managing risks derived from economic, environmental and social developments.

Sustainability in civil construction has been the subject of studies in the most diverse areas [2,7,9,24-27] ranging from selecting materials which have less impact on the environment, reducing the consumption of energy and the use of water, to reducing costs, etc., throughout the chain. It seeks to ensure that actions are taken to reduce environmental impacts, enhance economic process viability and provide a good quality of life for current and future generations, before, during and after construction phase.

The civil construction industry produces a significant amount of waste seen as a sustainability problem in construction. This problem must be solved by employing a cultural change in cities' governance models using tools, methodologies and long-term planning to seek innovative and green solutions to use resources rationally, minimizing the environmental impact [3].

Sustainable construction seeks to follow the premises of sustainable development so as not to deplete planetary resources and to develop environmentally correct methods of production and consumption, which guarantee the survival of ecosystems without abdicating the evolution of technology, to minimize the effects of construction on the environment, without jeopardizing the natural and technological development [10].

According to previous studies, sustainability in civil construction presents benefits, including the conscious consumption of raw material, the reuse of waste and the minimization of waste. Thus, among the main advantages of sound sustainable practices in civil construction are cost reduction, through process optimization, and tax incentives; more comfort for owners, guaranteed by sustainable architectural care related to thermal, light and other environmental factors; and a better sales argument, since the concept of sustainability is well valued in the contemporary world $[7,9]$.

In view of the theme, it was verified in the literature that one of the most challenging phases in a sustainable construction project is choosing the materials that will be used, because in addition to their physical-mechanical and technological properties, what is also necessary is to analyze them economically and socially and to determine the environmental impact that they generate throughout their entire life cycle. Among the main requirements analyzed when choosing materials, what the construction industry has given the most consideration to are the sustainability indicators for energy consumption and $\mathrm{CO}_{2}$ emissions [25,28].

In addition to the concern during the planning and execution of construction works as to energy consumption, another important concern is with the waste material generated and with demolition [29,30]. Ding, Wang and Zou [31] showed that about 30 to $40 \%$ of the waste generated in China comes from construction and demolition and that this waste needs to be managed. Their study showed that appointing a "green" manager and managing the stakeholders are decisive factors for reducing the impacts generated by waste materials, and thus the authors encouraged the use of deconstruction technologies and recycling.

Yeganeh, Azizi and Falsafi [17] developed a qualitative study to identify construction project problems and their causes, to understand how and why the events occur. They conducted interviews with specialists to identify problems and their causes and make recommendations to solve them [17]. Another study was carried out by Aziz [16] examining the causes and non-conforming impacts that cause environmental problems. For this, a case study was carried out. The construction plan approval of the building under analysis was used and the damage to the environment was explored. A detailed analysis of the possible root causes in terms of lack of awareness, lack of knowledge of building 
regulations, financial profitability, lack of space, strict building regulations and so on was carried out [16].

Seyis, Ergen and Pizzi [18] explored the causes and consequences of types of waste in the green construction project delivery process. A systematic literature review and a case study were carried out for identifying and classifying the main types of primary waste associated with the causes found in the design phase. This study explored large-scale construction projects by a general contractor, and data were collected using semi-structured interviews with five members of the project team. The Delphi method was applied to classify waste and identify primary and secondary causes that were correlated to assist project managers [18].

Then, the studies presented in the literature are studied for their construction projects' causes and their problems; causes and nonconformity impacts that lead to environmental effects; and the identification of waste types associated with their causes. Therefore, no studies were found that identify barriers for the implementation of sustainability in civil construction, namely preventive barriers to reduce threats that can cause an event, and protective barriers to reduce the effects of the consequences of an event. Thus, we propose the use of the bow-tie tool in sustainable civil construction projects to fill this gap in the literature, given the relevance of considering a structured analysis for understanding the causes, consequences and factors that can support the implementation of sustainability in the civil construction industry.

\section{BOW-TIE}

Bow-tie is a technique that combines fault trees and event trees to provide an estimate of the underlying risk of a selected dangerous event. Fault trees and event trees are linked through a dangerous event, which is the main event. Thus, a cause and effect model can be obtained for a dangerous event which is expressed in a diagram in the shape of a bow-tie [19]. It provides a graphical representation of threats upstream and consequences downstream [21], thus facilitating the identification of preventive control measures and, if the unwanted event still occurs, contingencies to mitigate the consequences [32].

The elements of the diagram can be defined as: hazard (an object or conditions with a potential to cause losses); threat (potential cause of initiating the risk scenario that leads to the central event); prevention barrier (protective measures to prevent threats that can lead to the risk scenario); top event (the event that sparks the risk scenario, i.e., the point at which control over the risk is lost); consequence (possible consequences resulting from the occurrence of the central event); and recovery measures/protection barriers (measures to mitigate the consequences). Thus, to create a bow-tie diagram, the top (main) event must be defined; this is placed at the center of the diagram. A main event can be triggered by one or more causes (threats). The threats are on the left side of the bow-tie diagram. The top (main) event leads to a series of consequences, which are placed on the right side of the diagram [21].

\section{Materials and Methods}

This study sets out to propose a structure to analyze the obstacles to implementing sustainable practices in construction works in the planning stage of sustainable construction projects, with an emphasis on the management and construction materials area, using the bow-tie tool. The tool is used to assess the impacts of these materials, the benefits that can accrue from more sustainable practices and to make suggestions for organizations in decision making. To this end, a study was carried out, through the analysis of three cases, in which the data were obtained by interviewing specialists of each company and undertaking documentary analysis. The cases chosen were those which have implemented sustainable practices, with indication by the company of specialists that have had experience of managing sustainable construction projects being required. 
The type of construction works analyzed was vertical buildings and the interview script was drawn up, with the objective of obtaining the steps for the bow-tie methodology, which consists of identifying the main event, identifying the causes/contributing factors of this event and establishing preventive barriers (Table 1).

Table 1. Cases and specialists in this study.

\begin{tabular}{|c|c|c|}
\hline Case 1 & Case 2 & Case 3 \\
\hline $\begin{array}{l}\text { Civil engineer, entrepreneur and } \\
\text { consultant in the construction } \\
\text { industry, with whom there was } \\
\text { discussion about wastages of } \\
\text { construction materials in general, } \\
\text { in accordance with his experience } \\
\text { in the region. }\end{array}$ & $\begin{array}{l}\text { Civil engineer, entrepreneur in plastering } \\
\text { services, with whom there was a more } \\
\text { specific discussion about plaster wastage, } \\
\text { and about the supplier's point of view. } \\
\text { The company in question adopts plaster } \\
\text { reuse and recycling practices during its } \\
\text { production process. }\end{array}$ & $\begin{array}{l}\text { Civil engineer, construction entrepreneur, } \\
\text { with extensive experience in the area of } \\
\text { sustainability. In this scenario, the planning } \\
\text { activity of a large commercial enterprise } \\
\text { was discussed, which used sustainable } \\
\text { practices during construction, emphasizing } \\
\text { the main event from the point of view of } \\
\text { opportunity, with improvements in the } \\
\text { objective of the project. }\end{array}$ \\
\hline
\end{tabular}

These interviewees (specialists) addressed in the study in each case are engaged with sustainability actions that have been developed in the studied region. As the aim of our study is the proposal of a structured methodology to identify causes, effects and protection and mitigation barriers associated with the issue of sustainability in the civil construction industry, we do not seek statistical generalization, but rather to demonstrate how the methodology can be useful for the problem, addressing three different scenarios, and how the use of the proposal can be helpful to analyze it. Then, we reached the face validity, of a non-statistical nature, based on the subjective judgment of the expert. The experts were involved throughout the research, having a minimum of two iterations [33].

The data were collected based on the steps of bow-tie. For this purpose, a semi-structured interview script was prepared to gather information and opinions on: the potential risk, the protection and prevention barriers and the causes and consequences of the risks mentioned. After finalizing the script, a selection was made of cases to be studied. These were defined based on the company's experience of seeking to address sustainability issues and in order to address how best to tackle these issues in three different types of construction project: a vertical project, another from the point of view of the subcontractor and the third was a project for a commercial construction. Each of the three companies nominated an interviewee (professional expert), who provided data that would be used to apply bow-tie and to construct a diagram of the protection barriers, and to show the causes and possible consequences of the main event for the company. The interaction among the analyst and the expert during the bow-tie application was as follows. First of all, an interview with the expert involved was carried out, defining the main event and collecting the information according to the questions already prepared for the application of the bow-tie. Based on the answers, the contributing factors were identified, and in another round, these factors were explained, with the preventive barriers built together (the expert, the analyst). Subsequently, the consequences were identified, and the protective barriers were identified. An analyst analyzed the data obtained, complemented with a documental analysis (some records provided). The final diagram was built using BowtieXP 2.9.6 software (CGE Risk Management Solution, Leidschendam, The Netherlands). After the expert analysis of the results on the diagram, adjustments were made, and the final version of the diagram was obtained. This process was repeated for each company. It identified barriers needed to implement sustainability in the civil construction industry (Figure 1). 

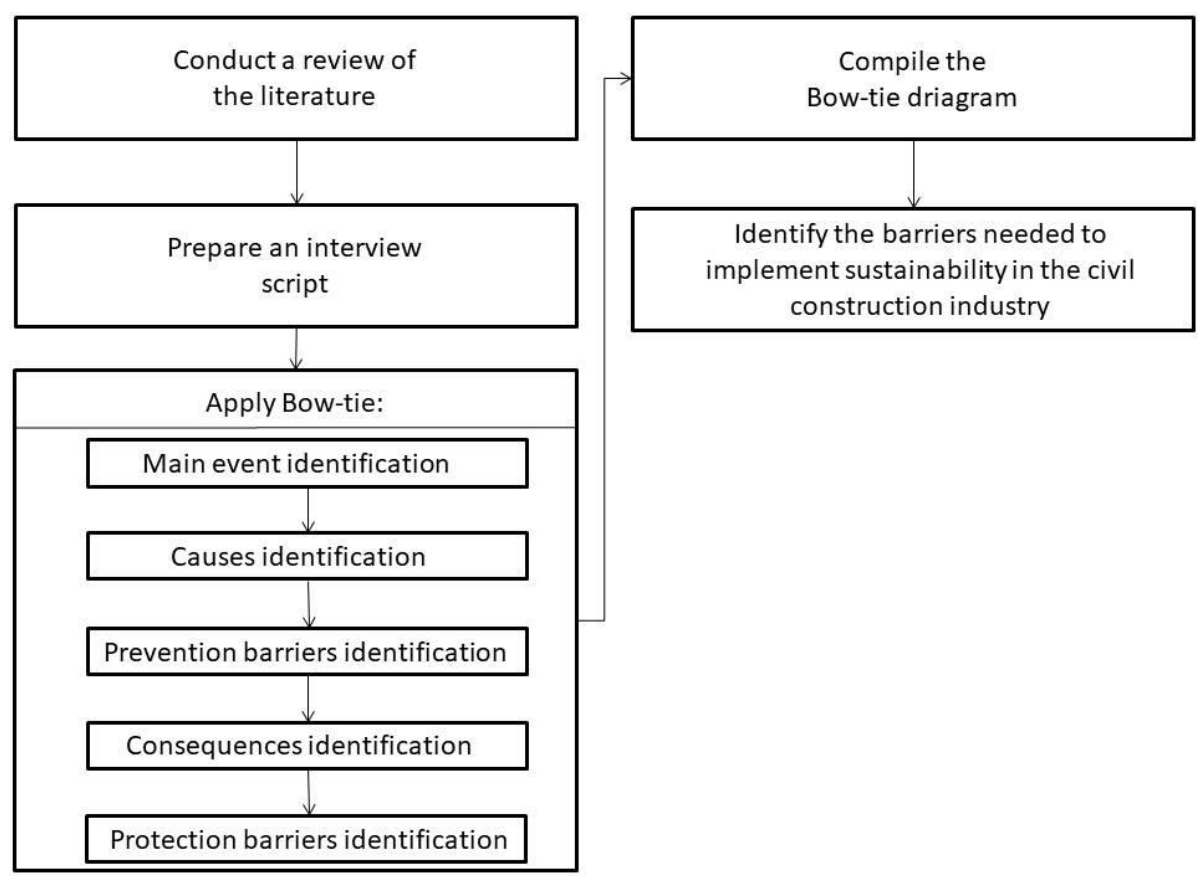

Figure 1. Framework for identification of barriers to implement sustainability in the civil construction industry.

\section{Results}

Given the above, three case studies were conducted. The first case study was based on vertical works (Figure A1 in Appendix A), while the second case study was related to specific plaster material, as it was a generic event (Figure A2 in Appendix A). Finally, the third case study addressed sustainable practices (Figure A3 in Appendix A). The case studies were conducted in accordance with the steps described in the diagrams.

\subsection{Case 1}

This first case was based on the planning stage of a project, to be carried out in Recife, to construct sustainable vertical buildings, which, on average, will have 30 floors. These are the most commonly found construction works in the region.

According to the expert of the present study, among the existing risks in the civil construction industry, that of building materials is one of the priorities, being the one most addressed among the current studies related to the theme of sustainability in construction works $[34,35]$.

One of the great risks related to materials, when looking for ways to make the work less unsustainable, is related to wastage [10]. This wastage can occur in two situations, the one most cited being the waste materials generated at the end of carrying out the service or by rework, or also when the specifications in the technical standards cannot be met. Thus, the wastage of construction materials is the main event of this scenario.

Several factors contribute to the wastage of materials at a construction site (Table 2). The threats listed are mainly linked to points aimed at the construction process, and involve technical issues, issues related to the manual labor force and issues involved in administering materials. Based on these factors, some preventive barriers can be introduced. These barriers are a form of prevention to avoid the factors listed above which contribute to generating the potential risk. For each threat, a barrier was designed, as shown in Table 2. 
Table 2. Barriers to prevent the wastage of materials.

\begin{tabular}{|c|c|}
\hline Contributory Factors & Preventive Barrier \\
\hline Inadequate construction techniques & $\begin{array}{c}\text { Planning; } \\
\text { mechanization and automation }\end{array}$ \\
\hline Lack of mastery of construction techniques & $\begin{array}{c}\text { Training } \\
\text { Drawing up procedures }\end{array}$ \\
\hline $\begin{array}{l}\text { Procedures for performing services } \\
\text { inadequate/outdated }\end{array}$ & Investment in quality programs \\
\hline Inadequate labor & Selection and training of manual laborers \\
\hline $\begin{array}{l}\text { Lack of professionals with knowledge in } \\
\text { management and project management }\end{array}$ & Selection and training \\
\hline Inadequate selection of materials (quality) & $\begin{array}{l}\text { Teams with experience about technical questions and management } \\
\text { of procurement } \\
\text { Use techniques for selecting/assessing suppliers }\end{array}$ \\
\hline Stock/packaging inadequate within the site & $\begin{array}{l}\text { Use of pallets } \\
\text { Draw up design of site }\end{array}$ \\
\hline $\begin{array}{l}\text { Lack of control methods of materials during the } \\
\text { execution of the work }\end{array}$ & Use methods for controlling materials \\
\hline Non-use of the delivery schedule with the supplier & Scheduling of deliveries with the supplier \\
\hline Delivery by the supplier of the material on site & $\begin{array}{l}\text { Use inspection of materials techniques in the act of delivery and } \\
\text { establish minimum requirements for acceptance of the material }\end{array}$ \\
\hline $\begin{array}{l}\text { Inadequate transfer of material between works of the } \\
\text { same company }\end{array}$ & Policies for the adequate storage, control and distribution of materials \\
\hline Inadequate transport within the site & $\begin{array}{c}\text { Distribution of materials (quantity) before carrying out the service as } \\
\text { per estimated consumption } \\
\text { Use of adequate moving equipment }\end{array}$ \\
\hline
\end{tabular}

Some measures must be taken if the risk occurs. These measures are called protective barriers. They serve to neutralize or minimize the consequences caused by the unwanted event. In the case of wastage of construction materials, the protective barriers are more focused on understanding the risk and learning lessons for future construction works, thus avoiding this wastage being repeated. The barriers found were: training, investment in technology, actions of registering and monitoring services for later analysis (registration of services on checklists, analysis of the appropriations of the services performed - consumption of material and man-hours) and reuse of material (applying leftovers in other smaller, associated services), e.g., leftover material from concreting being used to concrete small parts such as counter beams for masonry.

Every unwanted event has a set of causes, which can generate a set of consequences. These consequences are the effect that risk brings to the environment or to its stakeholders. In the case of this study, the main consequences are: increased cost, increased production time, greater environmental impact, higher expenditure of work for the manual labor force, interference in the final quality of the work, rework and the impact on the company's image.

These impacts can directly affect the objectives of the project, especially the costs, since the extra expenditure on the material used wrongly and the extra cost of the manual labor force cannot be recovered.

From the point of view of sustainability, the wastage of materials directly affects the three pillars of sustainability, namely the economic, social and environmental pillars. The increase in costs directly impacts the economic pillar. The increase in production time and expenditure of energy of the labor force impacts the social pillar. The impacts on the environment caused by using the materials and generating waste affect the environmental pillar.

After collecting the data, the BowtieXP 2.9.6 software was used to draw up the diagram. The diagram serves to make it easier for all members of the team to visualize the main causes and consequences of a given event, thus facilitating prevention and decision making regarding the possible controls of this risk. In the figure below, a generic model is presented for the control of the risk of wastage of materials (Figure A1 in Appendix A). 
It was found that the main causes for wastage are related to factors linked to the construction technique, management of the manual labor force and materials management. These causes can lead to increased costs, increased production times and a greater impact on the environment. To minimize the risk or impacts generated, prevention and protection barriers were suggested.

\subsection{Case 2}

Since this is a generic event, it is not possible to go into greater detail on the previous diagram. For this reason, a case study was developed for a specific material-plaster.

Gypsum was selected due to it being easily acquired in the state, as it is a low-cost material and widely used in construction works in the metropolitan region of Recife. The main event that was worked on was the wastage of plaster in vertical works in the metropolitan region of Recife, from the supplier's point of view. The main way of using plaster in local constructions is in the form of paste and plasterboard, the paste for cladding being the form that brings about the greatest losses during the process.

The wastage of gypsum derives from the same contributing factors as dealt with previously, but preventive barriers are more specific for gypsum, as can be seen in the table below (Table 3).

Table 3. Factors that contribute to and barriers that prevent the wastage of gypsum.

\begin{tabular}{|c|c|c|}
\hline Contributory Factor & Description & Preventive Barrier \\
\hline Inadequate construction techniques & $\begin{array}{c}\text { Masonry made with poor quality, implies a greater } \\
\text { amount of plaster paste necessary for leveling the } \\
\text { coating due to the lack of plumb lines and squares } \\
\text { on the walls }\end{array}$ & $\begin{array}{l}\text { Training of the manual labor force } \\
\text { Quality management of the masonry service } \\
\text { Modernization/adjustment of the } \\
\text { construction techniques }\end{array}$ \\
\hline Lack of mastery of construction techniques & $\begin{array}{l}\text { Low use of drywall in the region } \\
\text { Need to meet NBR } 15575\end{array}$ & $\begin{array}{l}\text { Modernization of the construction techniques } \\
\text { Incentive to industrialization } \\
\text { Change of the organizational culture } \\
\text { Compliance with NBR 15575, on the performance of } \\
\text { residential buildings }\end{array}$ \\
\hline $\begin{array}{l}\text { Procedures for performing services are } \\
\text { inadequate/outdated }\end{array}$ & $\begin{array}{l}\text { Preparation of large amounts of paste at one time, } \\
\text { losing the point of sticking on before finalizing the } \\
\text { service, thus generating wastage of material }\end{array}$ & $\begin{array}{l}\text { Training of the manual labor force } \\
\text { POP with instructions on preparing plaster paste } \\
\text { Work order with required quantities per floor }\end{array}$ \\
\hline Lack of organization during the service & $\begin{array}{l}\text { Disorganized and dirty construction site, thus } \\
\text { making the reuse of the material unviable }\end{array}$ & $\begin{array}{c}\text { Clean the area and use plastic tarpaulin before the start } \\
\text { of the service, to collect the leftovers and later reuse } \\
\text { Draw up inspection checklist for freeing area for } \\
\text { the plasterers }\end{array}$ \\
\hline Inadequate manual labor force & $\begin{array}{l}\text { An unprepared and/or untrained manual labor } \\
\text { force generates greater wastage }\end{array}$ & $\begin{array}{c}\text { Selection } \\
\text { Training of manual labor force on the conduct of } \\
\text { services, notions of quality, organization of the } \\
\text { construction site, handling of materials }\end{array}$ \\
\hline $\begin{array}{l}\text { Inadequate stock/packaging within the } \\
\text { construction site }\end{array}$ & $\begin{array}{l}\text { For powder plaster, the bags must be stacked } \\
\text { horizontally on pallets and panels, vertically, } \\
\text { without contact with the ground } \\
\text { Store so as to protect from the sun and bad weather }\end{array}$ & $\begin{array}{c}\text { Draw up design of site } \\
\text { Technical cards indicating where the materials are } \\
\text { Pallets for the stacking of the material } \\
\text { Training of manual labor force }\end{array}$ \\
\hline $\begin{array}{l}\text { Lack of methods for controlling } \\
\text { materials during the execution of the work }\end{array}$ & $\begin{array}{l}\text { The lack of a control card does not let the volume } \\
\text { used be monitored }\end{array}$ & Adopt control cards \\
\hline $\begin{array}{l}\text { Non-use of delivery schedule with } \\
\text { the supplier }\end{array}$ & $\begin{array}{l}\text { On average, the validity of gypsum powder is } \\
\qquad 3 \text { months }\end{array}$ & Adopt delivery schedule \\
\hline
\end{tabular}

In the case of the wastage of plaster, the protective barriers are more focused on recycling the waste, and the barriers found are: training/qualification of the manual labor force, investment in technology, actions of registration and monitoring of services for further analysis (registration of services on verification sheets, analysis of the appropriations of the services performed (consumption 
of material and man-hours)), separation of plaster waste, correct waste packaging, recycling of waste, reuse of material, design of the construction site and a marketing campaign evidencing reuse practices.

Every unwanted event has a set of causes, which can generate a set of consequences. These consequences are the effect that risk brings to the environment or to its stakeholders. With regard to this study, the main consequences are: a greater adverse impact on the environment, increased costs, increased production time, greater expenditure on the manual labor force, interference in the final quality of the work and image of the company that performs the plaster services.

The impacts generated by gypsum are mainly environmental, because, as it is a low-cost material and even though wastage is around 10 to $12 \%$ per building, the final increase in costs is negligible when compared to other materials. However, the environmental impacts generated are high, because if this waste material is not disposed of correctly, as defined by CONAMA resolution 431/11 [36], it can generate toxic gases and it can contaminate groundwater, amongst other harmful impacts.

The event was assessed by estimating the possibility of the consequence occurring. This was done using a standard risk matrix, which represents a possible scenario in which all paths and barriers are shown. This method uses the risk matrix to assess and categorize threats and then a more detailed analysis is conducted in terms of risk acceptance criteria. Finally, a set of improvement strategies is proposed which takes account of the existence and effect of contributing factors, the number of preventive and protective barriers and their effectiveness. In other words, it is a mapping of the probability and consequence of risk, represented by different colors. This enables the degree of risk to be graded based on the probability and severity of the consequences [21,37].

The scale was defined from 1 to 5 , according to the impact on the objectives of the work, using the expert's opinion and based on the study which used the bow-tie methodology in the health context to improve patient safety, and thus, through specialists in the field, a figure was adapted to the context of civil construction (Table 4) [21].

Table 4. Scale of impact.

\begin{tabular}{|c|c|c|c|c|c|}
\hline $\begin{array}{c}\text { Classification } \\
\text { Objectives }\end{array}$ & Very Low & Low & Moderate & High & Very High \\
\hline & 1 & 2 & 3 & 4 & 5 \\
\hline Time & No significant impact & Increase less than $5 \%$ & Increase of $6-10 \%$ & Increase of $11-19 \%$ & $\begin{array}{c}\text { Increase greater } \\
\text { than } 20 \%\end{array}$ \\
\hline Environmental & $\begin{array}{c}\text { No environmental } \\
\text { damage }\end{array}$ & $\begin{array}{l}\text { Minimal effects on } \\
\text { the environment }\end{array}$ & $\begin{array}{l}\text { Moderate effects on } \\
\text { the environment }\end{array}$ & $\begin{array}{l}\text { Strong effects on the } \\
\text { environment }\end{array}$ & $\begin{array}{l}\text { Severe effects on } \\
\text { the environment }\end{array}$ \\
\hline
\end{tabular}

The consequences were attributed considering the worst possible results. The risk occurrence scale was scored on a scale from 1 to 5 , in which the higher the number, the greater the probability of occurrence of the adverse outcome (Table 5).

Table 5. Scale of occurrence of wastage.

\begin{tabular}{cccccc}
\hline & Rare & Improbable & Possible & Probable & Almost Certain \\
\hline Score & $\mathbf{1}$ & $\mathbf{2}$ & $\mathbf{3}$ & $\mathbf{4}$ & $\mathbf{5}$ \\
\hline Score & $\begin{array}{c}\text { In less than } 10 \% \\
\text { of the works }\end{array}$ & $\begin{array}{c}\text { In between } 10 \% \text { and } \\
29 \% \text { of the works }\end{array}$ & $\begin{array}{c}\text { In between } 30 \% \text { and } \\
59 \% \text { of the works }\end{array}$ & $\begin{array}{c}\text { In between } 60 \% \text { and } \\
89 \% \text { of the works }\end{array}$ & $\begin{array}{c}\text { In more than } \mathbf{9 0} \% \\
\text { of the works }\end{array}$ \\
\hline
\end{tabular}

The impact of waste plaster was calculated. The main objective affected was considered to be the impact on the environment. The expert considered that waste plaster should receive a score of moderate risk, since it can generate severe damage on the environment, and can cause moderate impacts to the physical, biotic or anthropic environments. This requires immediate corrective actions to 
prevent the impact growing into a catastrophe. The possibility of irreparable environmental accidents is remote. As for the occurrence, the expert ruled that the wastage of plaster is likely to occur in the construction sites in the region, as it is an event that occurs in most of them.

Risk scores were calculated by multiplying the impact score by the occurrence score, using a scale from $1 \times 1=1$ to $5 \times 5=25$. As can be seen in the matrix (Figure 2), the risk assessed can be classified into up to four levels: very low risks (low risk, green part of the matrix); tolerable risks (moderate and high risks, yellow and orange parts of the matrix, respectively); and intolerable or unacceptable risks (very high risk, red part of the matrix). In the problem in question, a score of 15 was obtained (moderate impact scale $=3 \times$ almost certain occurrence scale $=5$ ), one being considered a very high risk. High risk requires protection barriers to minimize the impact on the environment, and they should be brought into use as soon as possible.

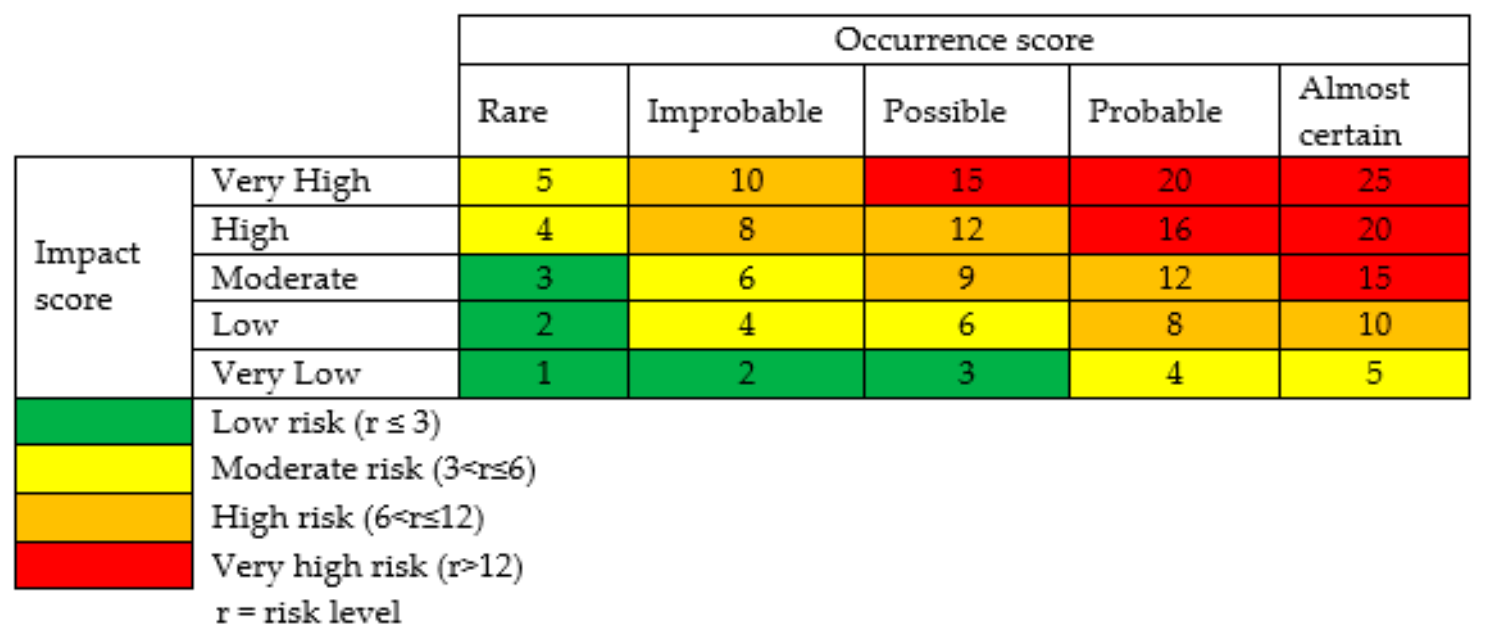

Figure 2. Risk matrix. Source: adapted from [21].

With all the steps completed, the diagram was constructed with the aid of the BowtieXP 9.2.6 software. In the diagram below, on the right side, the main causes and prevention barriers to avoid the risk can be checked. On the left side, the possible consequences and protection barriers, in case the risk occurs, can be checked.

The main causes of the wastage concern factors related to construction techniques, management of the manual labor force and materials management. These causes can mainly generate a greater impact on the environment. To minimize the risk or impacts generated, prevention and protection barriers were suggested, emphasizing in this case, the importance of the correct disposal of this material, in addition to reuse and recycling (Figure A2 in Appendix A).

\subsection{Case 3}

Unlike the previous cases, there are cases of successful sustainable practices in the metropolitan region of Recife. As a case study, data were collected on a commercial site, where sustainable techniques have been used ever since the construction works started.

Risks are adverse events that affect the objectives of the project and can be negative, such as threats, or positive, such as opportunities. In this case, the risk was addressed in the form of an improvement, i.e., as an opportunity. The main event was called planning. Planning was deemed to be a fundamental activity, since based on planning, all of the survey is about the demands that must be met for the construction project.

According to the expert, three factors are fundamental to guarantee the efficiency of a sustainable project: meeting the demand for technical standards, designing a rational construction site and choosing industrialized construction systems. 
Some points were thought about and implemented during the planning of the construction work, namely: compliance with technical norms, building standards, safety measures, safety at heights, rational project design, use of the BIM platform, management plan for waste materials, design of energy efficiency, design of appropriate sanitation, plan for managing stakeholders, management plan for surrounding areas, plan for urban environmental management, quality management of processes, training the manual labor workforce, demolition planning and area preparation, study of the soil, reuse of residues generated during demolition and listing of the environmental reserve area. These were the main causes and preventive barriers which the specialist considered to support the activity of planning for the site.

After the initial planning, some actions help to improve the results obtained by doing this activity. These are:

- Development of the Programa Obra Limpa (Clean Works Program)—Plan for Controlling Impacts on the Construction Site which sets out 88 sustainability strategies, which are divided into 9 distinct categories (Pollution Control During Construction Activities, Management of Construction Waste, Rational Use of Drinking Water, Humanization of the Construction Site, Energy Efficiency, Quality of the Internal Environment for Employees and Future Occupants of the Building, Responsible Management of Forest Resources, Purchase of Materials of Lesser Environmental Impact, Indicators of Sustainability of the Construction Work);

- Use of LEED (Leadership in Energy and Environmental Design) certification;

- Use of performance indicators in the different management areas;

- Skills training of manual labor force for the construction stage and for the operation and maintenance stage of the works.

On using this program, the following results were achieved: decrease in construction costs of around $8 \%$; decrease in operating costs of around $20 \%$; improvement in the quality of operations; lesser impact on the environment; less time taken to do the work-gains in productivity; and enhancement of the company's image.

Some of the program's sustainability indexes generated significant numbers. The actions carried out in this program resulted in savings of more than BRL 1 million and approximately 16,000 tons of waste was sent for recycling. The waste material that was generated by demolishing the old building was recycled after it was crushed and then reused as an aggregate in construction processes. This led to a decrease of more than 3000 truck journeys during the work, this representing a reduction of around $27,000 \mathrm{~L}$ in the consumption of fossil fuels and of 88 tons of $\mathrm{CO}_{2}$ emission. In other words, the impact on the environment was lessened.

The results obtained showed how well-articulated and executed planning brings gains in all of the design objectives, thereby ensuring rational construction and efficient processes.

After collecting the data, the bow-tie diagram for the planning event was built, using the BowtieXP 9.2.6 software, as shown in the figure below. It is important to note that in the diagram, only the main points that were dealt with to ensure sustainability in the construction works studied were allocated (Figure A3 in Appendix A).

Unlike the previous scenarios, scenario 3 brought risk analysis from the point of view of risk as an opportunity, i.e., to improve the objectives of the project. The event analyzed was the planning activity of the construction project of a commercial enterprise in the RMR, which used sustainable practices during construction.

For the specialist, the main factors that influence good planning and ensure sustainable practices are applied as follows: compliance with the regulatory standards, the design of a rational construction site and the choice of the construction technique. These factors led to a decrease in the total cost of production and operation of the project, in addition to lessening the impact on the environment. Prevention and protection barriers were aimed at facilitating planning and obtaining the estimated results. 
This scenario demonstrated that when they are well-planned and executed, sustainable practices bring good results for the organization, society and environment.

According to the structure of the bow-tie diagram, it is possible to integrate cause and effect in a same view and analysis, identifying the main causes of potential problems to implement sustainability in construction, as well as identifying opportunities to suggest the most sensible and correct use to improve sustainability practices and assist in decision making. Further, the work served to raise the main problem that causes obstacles to the implementation of green practices in civil construction and identify the relevant issues of management and planning for good development and a viable and practical application, collaborating for the success of the project.

\section{Concluding Remarks}

According to the results obtained in the study, some points were observed: the main causes and consequences of the events were revealed and, from these, barriers of prevention and protection were traced and implemented.

The causes related to the problems of material waste (scenarios 1 and 2), in general, concern issues related to the choice of construction technique, lack of mastery of construction technique, general disorganization of the construction site, problems related to labor, and issues related to material management, such as poor storage, handling problems and lack of distribution control. These factors, if not controlled, generate increased costs, rework and, consequently, the workforce spends more energy and takes time to perform the service, in addition to having greater impacts on the environment. The study by Van Thuyet, Ogunlana and Dey [38] identified some causes related to material waste problems, making the deadlines correlated and costs exceeding. They justified, in a function of current projects that are more exposed to risks and uncertainties due to complexity in planning and design, the presence of various stakeholders (investors, consultants, suppliers, etc.), doubts about the availability of resources (materials, equipment, funds, etc.), the climate of the environment and social issues, as well as legal, economic and political factors. Tomovsca and Radivojevic [39] stated that only sustainable architecture could be achieved by a simple and careful application of local construction materials and techniques, while in this research, it was seen that the main barriers were related to the planning of construction techniques and to the use of industrialized processes in order to reduce the amount of waste generated and save operating time. Another important barrier concerns the implementation of policies aimed at the organization of the construction site and quality management. A clean and organized place facilitates the execution of services, generating greater productivity.

Another important consideration is that this study revealed that at each stage of the life cycle, the amount of waste generated depends on the intensity of the construction activity, the technology used and the rates of waste and maintenance. In practice, all activities carried out in the civil construction sector have the potential to generate waste. This research showed that in the production phase, the primary explanation for the generation of construction waste is that there is a high volume of waste in construction materials. Further, the production of waste causes significant environmental damage throughout its life cycle due to the large consumption of natural aggregates, as this same discussion is also found in the study by Colangelo et al. [40], and the main phase that generates the most significant amount of waste is in production, but in the activity of the construction site, materials and demolition.

Another study presented a methodology to assist decision-makers in matters involving the management of materials, demonstrating the need for organization in the sector [41]. It is also noteworthy that, among the causes of both waste materials and plaster, the vast majority of cases, directly or indirectly, involve issues related to the unpreparedness of the workforce. Civil construction still presents in aspects of artisanal manufacture, where the role of the worker is decisive for the quality of the final product and is directly related to the sustainability of the sector. The level of training and qualification of manual workers reflects some fundamental issues for more sustainable construction, such as the rational use of inputs and the control of waste generation [10]. 
Many construction companies, contractors and subcontractors do not invest in training their staff to train their employees in all necessary processes, especially when there is a high turnover of manual labor, but also in the management of construction and demolition waste [42,43]. In general, these professionals lack adequate training during the work, but they have little or no knowledge about the physical, chemical and economic characteristics of each type of material, for example, wood, ceramic block, masonry block, iron and plaster. This also prevents them from being separated correctly, reducing the chances of reuse and recycling. Therefore, investment in skills training is fundamental to change general behavior and investments in changing organizational culture [44-47].

Barriers were also established in the case of waste, in order to neutralize or minimize it. The main barriers were directed to investment in technology and operations monitoring actions. The use of performance indicators allows to verify how the process is behaving and, therefore, allows its flaws to be identified.

In addition, waste management practices were also suggested, with subsequent reuse in the work or recycling, or at least the correct disposal of the waste. Thus, the area of waste management is fundamental for ensuring the sustainability of a construction project $[48,49]$.

In scenario 3, an example of the importance of planning for the sustainable project was seen, where the guarantee of meeting the technical standards, the design of a rational construction site project and the correct choice of the construction system were the basis for ensuring that costs and environmental impacts generated were reduced and that the quality of operations was higher. In other words, the search for the management of all areas related to sustainability, such as waste, quality, energy, water resources, environmental protection, surrounding areas and the well-being of those involved in the process, proved to be fundamental to guarantee the results expected. Thus, after implementing the program, the cost of the work was reduced by around $8 \%$ and the impact on the environment, mainly by improving waste management, resulted in less than $10 \%$ of waste materials being used as landfill. Using the BIM platform for this was also seen as essential throughout the process. The use of the BIM platform is advantageous since the coordination between participating designers and contractors is improved and omission errors are significantly reduced. This makes the construction process faster, reduces costs, minimizes the likelihood of design errors and provides a more efficient process for the entire project team [50-52]. Some of the sustainable practices adopted in projects were: waste management policies, reuse of demolition waste, recycling of organic waste and classes $\mathrm{A}$ and $\mathrm{B}$, water treatment station, sanitation station, power generation from renewable sources, installation of a concreting plant and less use of vehicles for material handling, with less consumption of fossil fuels. These practices, in addition to reducing impacts on the environment, also contributed to cost reduction. Several authors have discussed the importance of these practices in the construction system. Del Rey et al. [49], Bourdot et al. [48] and Barritt [53] presented the advantages of incorporating recycled aggregates in a different mix of concrete. Hasik et al. [54] showed ways to save energy in the works. Ding, Wang and Zou [31] discussed the importance of waste management, however, in these studies there is no application of a tool that explores, in a schematic and simple way, the descriptions and analyzes the paths of a risk, from its causes to its consequences. In addition, bow-tie's focus is on the barriers between causes and risk, and risk and consequences.

Therefore, we suggest that the main obstacles to implementing sustainability in civil construction are: lack of planning for a sustainable construction project; lack of compliance with pre-established technical standards; choosing inappropriate construction techniques; little industrialization in construction systems; lack of technical knowledge of the workforce about operations and services; lack of standardization and use of specific procedures in operations and services; lack of incentives and regulations aimed at waste management; and lack of more complete material management (control, storage and movement).

Thus, the prevention and protection barriers presented in the different scenarios are means to assist implementing sustainability in the civil construction industry. 
Limitations and future lines of research:

Finally, the research limitations of this paper were that the results discussed refer to the field study on the practices discussed by specialists in the region studied. These practices may vary according to the country of study, local organizational culture and specific legislation.

As to future lines of research, it is recommended that evaluation methods be drawn up to measure in the field the loss of material that originated from wastages, service execution errors, storage and handling errors and from generating residues, in addition to designing methods on reusing and recycling materials that have a high adverse impact on the environment.

Author Contributions: The authors contributed equally to this manuscript. All authors have read and agreed to the published version of the manuscript.

Funding: This research was funded by Coordenação de Aperfeiçoamento de Pessoal de Nível Superior grant number 001 and by Conselho Nacional de Desenvolvimento Científico e Tecnológico grant number 306760/2018-5; 305119/2017-6.

Conflicts of Interest: The authors declare no conflict of interest. 


\section{Appendix A. Figures of Results for Bow-Tie}

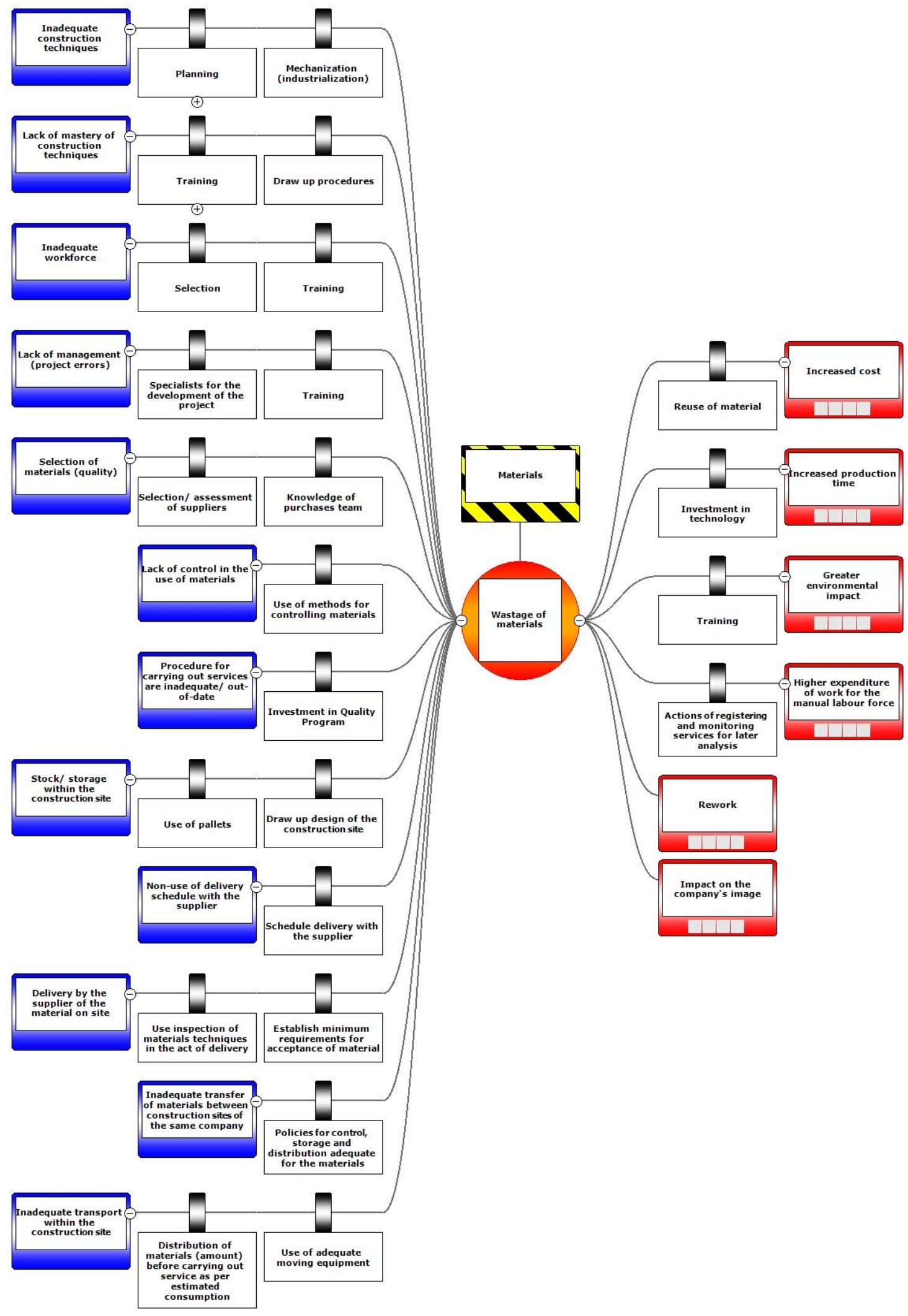

Figure A1. Bow-tie for wastages of materials. 


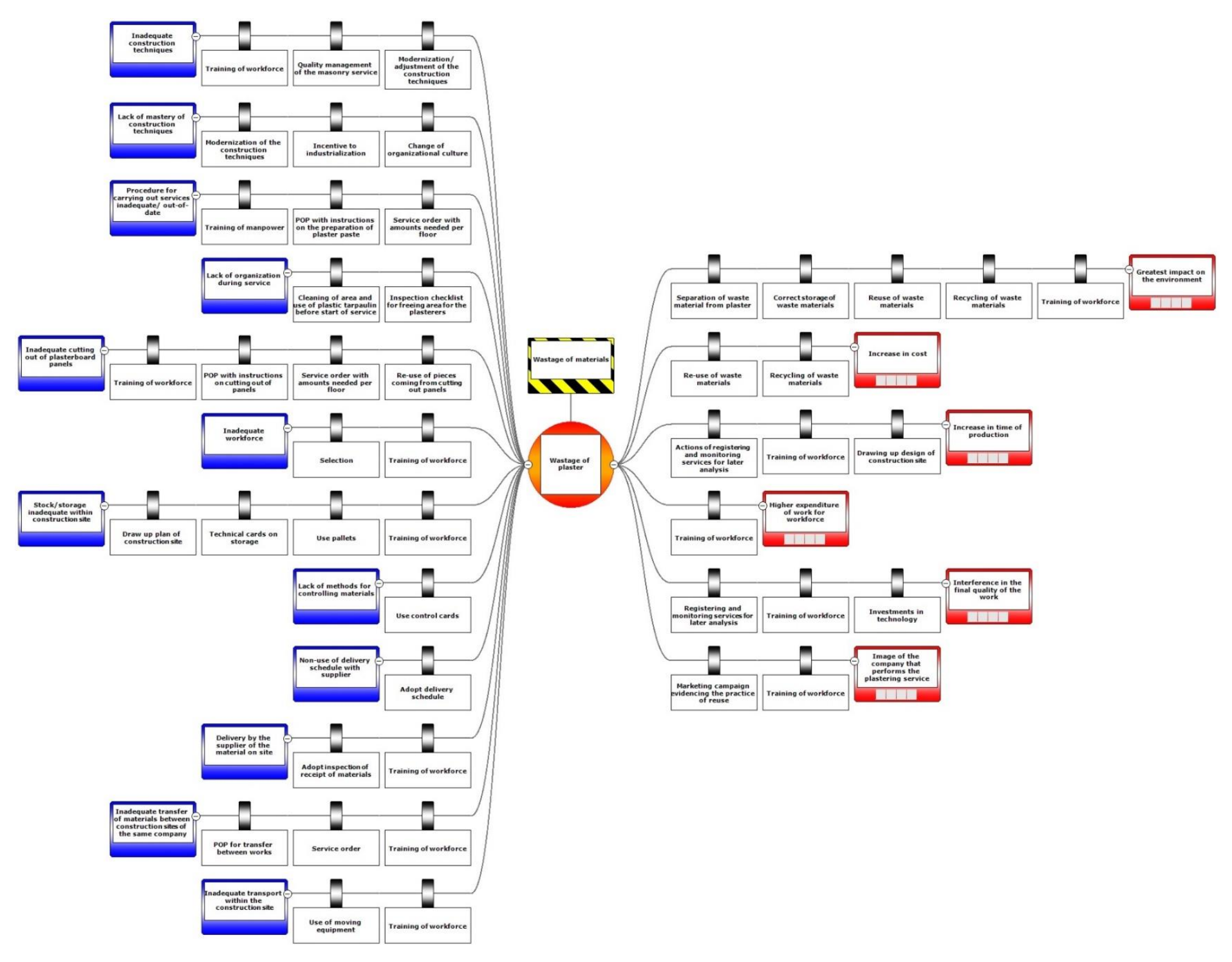

Figure A2. Bow-tie diagram for wastage of plaster. 


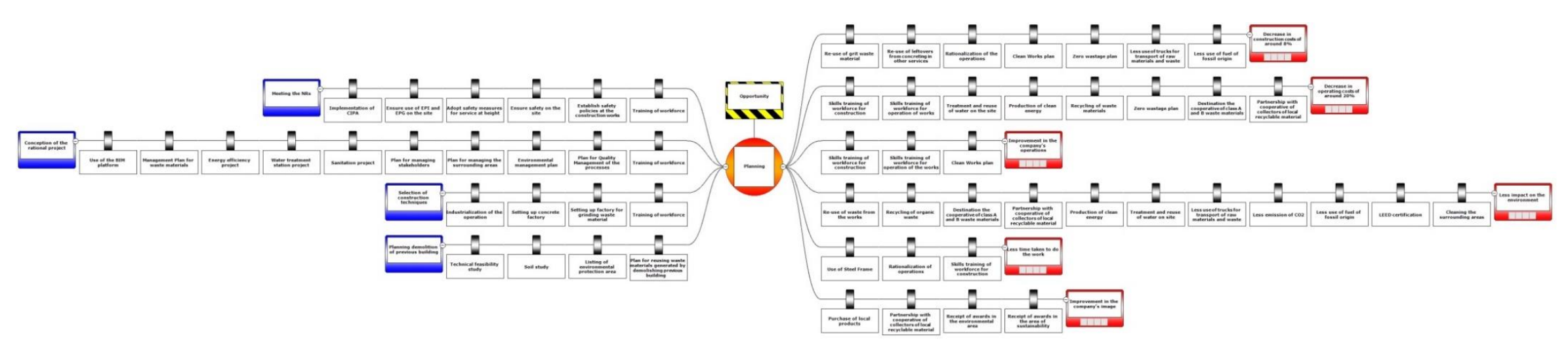

Figure A3. Bow-tie diagram for the activity of planning. 


\section{References}

1. Hossain, U.; $\mathrm{Ng}$, S.T. Strategies for enhancing the accuracy of evaluation and sustainability performance of building. J. Environ. Manag. 2020, 261, 110230. [CrossRef] [PubMed]

2. Pardo-Bosch, F.; Cervera, C.; Ysa, T. Key aspects of building retrofitting: Strategizing sustainable cities. J. Environ. Manag. 2019, 248, 109247. [CrossRef] [PubMed]

3. Pardo-Bosch, F.; Aguado, A.; Pino, M. Holistic model to analyze and prioritize urban sustainable buildings for public services. Sustain. Cities Soc. 2019, 44, 227-236. [CrossRef]

4. Jafari, A.; Valentin, V.; Bogus, S.M. Identification of Social Sustainability Criteria in Building Energy Retrofit Projects. J. Constr. Eng. Manag. 2019, 145, 1-11. [CrossRef]

5. Yim, S.Y.C.; Ng, S.T.; Hossain, U.; Wong, J.M.W. Comprehensive Evaluation of Carbon Emissions for the Development of High-Rise Residential Building. Buildings 2018, 8, 147. [CrossRef]

6. Smarzewski, P. Mechanical Properties of Ultra-High Performance Concrete with Partial Utilization of Waste Foundry Sand. Buildings 2020, 10, 11. [CrossRef]

7. Guo, D.; Huang, L. The State of the Art of Material Flow Analysis Research Based on Construction and Demolition Waste Recycling and Disposal. Buildings 2019, 9, 207. [CrossRef]

8. Thomas, J.; Harilal, B. Sustainability evaluation of cold-bonded aggregates made from waste materials. J. Clean. Prod. 2019, 237, 117788. [CrossRef]

9. Dos Reis, G.S.; Cazacliu, B.G.; Cothenet, A.; Poullain, P.; Wilhelm, M.; Sampaio, C.H.; Lima, E.C.; Ambros, W.; Torrenti, J.-M. Fabrication, microstructure, and properties of fired clay bricks using construction and demolition waste sludge as the main additive. J. Clean. Prod. 2020, 258, 120733. [CrossRef]

10. Priori, L., Jr.; Rego Silva, J.J. Sustainable management as an effective solution for the improvement of working conditions on building sites in the state of Pernambuco-Brazil. World Sustain. Build. Conf. 2011.

11. Luangcharoenrat, C.; Intrachooto, S.; Peansupap, V.; Sutthinarakorn, W. Factors Influencing Construction Waste Generation in Building Construction: Thailand's Perspective. Sustainability 2019, 11, 3638. [CrossRef]

12. Raouf, A.M.; Al-Ghamdi, S. Effectiveness of Project Delivery Systems in Executing Green Buildings. J. Constr. Eng. Manag. 2019, 145, 03119005. [CrossRef]

13. El Hajj, C.; Piatyszek, E.; Tardy, A.; Laforest, V. Development of generic bow-tie diagrams of accidental scenarios triggered by flooding of industrial facilities (Natech). J. Loss Prev. Process. Ind. 2015, 36, 72-83. [CrossRef]

14. Chen, X.; Shuai, C.; Chen, Z.; Zhang, Y. Science of the Total Environment What are the root causes hindering the implementation of green roofs in urban China ? Sci. Total Environ. 2019, 654, 742-750. [CrossRef]

15. Zhang, X.; Shen, L.; Tam, V.W.; Lee, W.W.Y. Barriers to implement extensive green roof systems: A Hong Kong study. Renew. Sustain. Energy Rev. 2012, 16, 314-319. [CrossRef]

16. Aziz, A. Examining the Root Causes of Deficient Building Control and Its Nonconforming Impacts in Lahore. J. Urban Plan. Dev. 2018, 144, 05018003. [CrossRef]

17. Yeganeh, A.A.; Azizi, M.; Falsafi, R. Root Causes of Design-Construction Interface Problems in Iranian Design-Build Projects. J. Constr. Eng. Manag. 2019, 145, 05019014. [CrossRef]

18. Seyis, S.; Ergen, E.; Pizzi, E. Identification of Waste Types and Their Root Causes in Green-Building Project Delivery Process. J. Constr. Eng. Manag. 2016, 142, 04015059. [CrossRef]

19. Vileiniskis, M.; Remenyte-Prescott, R. Quantitative risk prognostics framework based on Petri Net and Bow-Tie models. Reliab. Eng. Syst. Saf. 2017, 165, 62-73. [CrossRef]

20. Cardwell, G. The application of the Four Essentials Bow Tie Diagram to enhance business success. Total. Qual. Manag. Bus. Excel. 2008, 19, 37-45. [CrossRef]

21. Abdi, Z.; Ravaghi, H.; Abbasi, M.; Delgoshaei, B.; Esfandiari, S. Application of Bow-tie methodology to improve patient safety. Int. J. Health Care Qual. Assur. 2016, 29, 425-440. [CrossRef]

22. Silvius, A.G.; Kampinga, M.; Paniagua, S.; Mooi, H. Considering sustainability in project management decision making; An investigation using Q-methodology. Int. J. Proj. Manag. 2017, 35, 1133-1150. [CrossRef]

23. Martens, M.L.; Carvalho, M. Key factors of sustainability in project management context: A survey exploring the project managers' perspective. Int. J. Proj. Manag. 2017, 35, 1084-1102. [CrossRef]

24. Alencar, M.H.; Priori, L.; Alencar, L.H. Structuring objectives based on value-focused thinking methodology: Creating alternatives for sustainability in the built environment. J. Clean. Prod. 2017, 156, 62-73. [CrossRef] 
25. Samani, P.; Mendes, A.; Leal, V.; Guedes, J.M.; Correia, N. A sustainability assessment of advanced materials for novel housing solutions. Build. Environ. 2015, 92, 182-191. [CrossRef]

26. Woon, A.; Raman, S.N.; Safiuddin, M.; Jamil, M.; Zain, M. Development of an Assessment Method to Evaluate the Quality of Remedial Treatments on Concrete Flat Roofs of Multiple Buildings. Buildings 2019, 9, 124. [CrossRef]

27. Dodoo, A.; Ayarkwa, J. Effects of Climate Change for Thermal Comfort and Energy Performance of Residential Buildings in a Sub-Saharan African Climate. Buildings 2019, 9, 215. [CrossRef]

28. Gurgun, A.P.; Arditi, D. Assessment of Energy Credits in LEED-Certified Buildings Based on Certification Levels and Project Ownership. Buildings 2018, 8, 29. [CrossRef]

29. Tam, V.W.; Lu, W. Construction Waste Management Profiles, Practices, and Performance: A Cross-Jurisdictional Analysis in Four Countries. Sustainability 2016, 8, 190. [CrossRef]

30. Narcis, N.; Ray, I.; Hosein, G. Construction and Demolition Waste Management Actions and Potential Benefits: A Perspective from Trinidad and Tobago. Buildings 2019, 9, 150. [CrossRef]

31. Ding, Z.; Wang, Y.; Zou, P.X. An agent based environmental impact assessment of building demolition waste management: Conventional versus green management. J. Clean. Prod. 2016, 133, 1136-1153. [CrossRef]

32. Galvin, J. Critical role of risk management in ground engineering and opportunities for improvement. Int. J. Min. Sci. Technol. 2017, 27, 725-731. [CrossRef]

33. Lucko, G.; Rojas, E.M. Research Validation: Challenges and Opportunities in the Construction Domain. J. Constr. Eng. Manag. 2010, 136, 127-135. [CrossRef]

34. Chi, B.; Lu, W.; Ye, M.; Bao, Z.; Zhang, X. Construction waste minimization in green building: A comparative analysis of LEED-NC 2009 certified projects in the US and China. J. Clean. Prod. 2020, 256, 120749. [CrossRef]

35. Ioannidou, D.; Zerbi, S.; Habert, G. When more is better-Comparative LCA of wall systems with stone. Build. Environ. 2014, 82, 628-639. [CrossRef]

36. Conama Resolução No 431, de 24 de Maio de 2011. Available online: http://www2.mma.gov.br/port/conama/ legiabre.cfm?codlegi=649 (accessed on 1 November 2018).

37. Baybutt, P. Guidelines for designing risk matrices. Process. Saf. Prog. 2017, 37, 49-55. [CrossRef]

38. Van Thuyet, N.; Ogunlana, S.O.; Dey, P.K. Risk management in oil and gas construction projects in Vietnam. Int. J. Energy Sect. Manag. 2007, 1, 175-194. [CrossRef]

39. Tomovska, R.; Radivojević, A. Tracing sustainable design strategies in the example of the traditional Ohrid house. J. Clean. Prod. 2017, 147, 10-24. [CrossRef]

40. Colangelo, F.; Forcina, A.; Farina, I.; Petrillo, A. Life Cycle Assessment (LCA) of Different Kinds of Concrete Containing Waste for Sustainable Construction. Buildings 2018, 8, 70. [CrossRef]

41. Arroyo, P.; Tommelein, I.D.; Ballard, G. Selecting Globally Sustainable Materials: A Case Study Using Choosing by Advantages. J. Constr. Eng. Manag. 2016, 142, 05015015. [CrossRef]

42. Başağa, H.B.; Temel, B.A.; Atasoy, M.; Yıldırım, I. A study on the effectiveness of occupational health and safety trainings of construction workers in Turkey. Saf. Sci. 2018, 110, 344-354. [CrossRef]

43. Mbanaso, F.; Charlesworth, S.; Coupe, S.; Newman, A.; Nnadi, E.O. Reuse of materials from a Sustainable Drainage System device: Health, Safety and Environment assessment for an end-of-life Pervious Pavement Structure. Sci. Total. Environ. 2019, 650, 1759-1770. [CrossRef] [PubMed]

44. Emery, S.; Smith, D.; Gaterell, M.; Sammons, G.; Moon, D. Estimation of the recycled content of an existing construction project. Resour. Conserv. Recycl. 2007, 52, 395-409. [CrossRef]

45. Hamilton-MacLaren, F.; Loveday, D.L.; Mourshed, M. Public opinions on alternative lower carbon wall construction techniques for UK housing. Habitat Int. 2013, 37, 163-169. [CrossRef]

46. Karakhan, A.; Gambatese, J. Safety Innovation and Integration in High-Performance Designs: Benefits, Motivations, and Obstacles. Pract. Period. Struct. Des. Constr. 2017, 22, 04017018. [CrossRef]

47. Kim, J.T.; Yu, C.W.F. Hazardous materials in buildings. Indoor Built Environ. 2014, 23, 44-61. [CrossRef]

48. Bourdot, A.; Promis, G.; Le, A.D.T.; Douzane, O.; Benazzouk, A.; Rosquoët, F.; Langlet, T. Hygrothermal properties of blocks based on eco-aggregates: Experimental and numerical study. Constr. Build. Mater. 2016, 125, 279-289. [CrossRef]

49. Del Rey, I.; Ayuso, J.; Galvín, A.; Jiménez, J.R.; Barbudo, A. Feasibility of Using Unbound Mixed Recycled Aggregates from CDW over Expansive Clay Subgrade in Unpaved Rural Roads. Materials 2016, 9, 931. [CrossRef] 
50. Alwan, Z.; Jones, P.; Holgate, P. Strategic sustainable development in the UK construction industry, through the framework for strategic sustainable development, using Building Information Modelling. J. Clean. Prod. 2017, 140, 349-358. [CrossRef]

51. Jamil, A.H.A.; Fathi, M.S. Enhancing BIM-Based Information Interoperability: Dispute Resolution from Legal and Contractual Perspectives. J. Constr. Eng. Manag. 2020, 146, 05020007. [CrossRef]

52. Terreno, S.; Asadi, S.; Anumba, C.J. An Exploration of Synergies between Lean Concepts and BIM in FM: A Review and Directions for Future Research. Buildings 2019, 9, 147. [CrossRef]

53. Barritt, J. An overview on recycling and waste in construction. Proc. Inst. Civ. Eng. Constr. Mater. 2016, 169, 49-53. [CrossRef]

54. Hasik, V.; Anderson, N.E.; Collinge, W.O.; Thiel, C.; Khanna, V.; Wirick, J.; Piacentini, R.; Landis, A.E.; Bilec, M. Evaluating the Life Cycle Environmental Benefits and Trade-Offs of Water Reuse Systems for Net-Zero Buildings. Environ. Sci. Technol. 2017, 51, 1110-1119. [CrossRef] [PubMed]

(C) 2020 by the authors. Licensee MDPI, Basel, Switzerland. This article is an open access article distributed under the terms and conditions of the Creative Commons Attribution (CC BY) license (http://creativecommons.org/licenses/by/4.0/). 